\title{
FDM Cloud Based Application Performance Monitoring System of The Cadets While on Board Ship Training for the Philippine Merchant Marine Academy in San Narciso Zambales
}

\author{
FROILAN D. MOBO
}

General Education Philippine Merchant Marine Academy San Narciso, Zambales, Philippines.

\begin{abstract}
The main thrust of the study is to develop a cloud-based application performance monitoring system of the cadets while on board ship training for the Philippine Merchant Marine Academy in San Narciso, Zambales which intended to serve as an alternative system that can be used by the target school in monitoring the performance of the cadets while on ship board and determine its effectiveness. The researcher has used the descriptive research method wherein the study is focused on the present situations. It involves the recording, description and the presentation of the present system, composition and phenomena. The Statement of the problem focused in obtaining the effectiveness of the proposed cloud based application in performance monitoring system of the cadets for the Philippine Merchant Marine Academy, San Narciso, Zambales. Findings showed that the Department of Shipboard Training needs a real time system that can monitor the cadets while on board ship training. Based on the conclusion of this study, the researcher recommends the development of the cloud based application which will monitor the performance of the cadets while on board ship training and lastly, the developed system was tested during the implementation and met no errors. Based on the findings, the number of respondents as group per course is in parallel to the ratio of the students currently enrolled at PMMA. Majority of the respondents for both the groups came from the existing Group whose ages range from 19-21 years old.As revealed, the majority of the respondents for both the groups are males from the Proposed Group. In the proposed system out of one hundred percent respondents, thirty or $93.5 \%$ cadets; while the officials are nine or $6.5 \%$ of the one hundred, from the total of thirty-nine respondents.
\end{abstract}

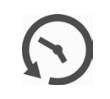

Article History

Received: 1 November 2017

Accepted:15 November 2017

\section{Keywords}

Cloud Based Application, Shipboard Training.

\footnotetext{
CONTACT DR. FROILAN D. MOBO froilanmobo@gmail.com $\mathbf{9}$ General Education Philippine Merchant Marine Academy San Narciso, Zambales, Philippines.

(C) 2017 The Author(s). Published by Techno Research Publishers

This is an Open Access article licensed under a Creative Commons Attribution-NonCommercial-ShareAlike 4.0 International License (https://creativecommons.org/licenses/by-nc-sa/4.0/), which permits unrestricted NonCommercial use, distribution, and reproduction in any medium, provided the original work is properly cited.

To link to this article: http://dx.doi.org/10.13005/ojcst/10.04.04
} 


\section{Introduction}

Technology nowadays is overwhelming that it has results change faster from a stand-alone system to a web based technology which is capable of supporting almost all of the computerized transactions using an open source mobile applet and Content Management Systems. Most of the organizations have embraced technology and have developed exceptional online programs that provide easy access and massive communication. Philippine Merchant Marine Academy (PMMA) is one of the premier maritime institutions whose advocacy is to produce competent maritime professionals and the only maritime school in the province of Zambales. The Philippine Merchant Marine Academy (PMMA) is currently divided into two colleges namely; the College of Bachelor of Science in Marine Engineering, and the College of Bachelor of Science in Marine Transportation. From the total of 2902 nd class cadets, 150 are B.S. Marine Engineering cadets and 140 are B.S. Marine who are currently having their on -board ship internship training in preparation for their fields of specialization as deck and engine officer.

A web-based Applet Monitoring System via CloudBased Application using Android and Joomla Technology can provide efficient and accurate monitoring of performance reports of the $2^{\text {nd }}$ class cadets. This intends to perform the following operations; analyze and transfer the gathered reports and eliminate circumstances of causing the delay of releasing reports; minimize the time consumed in searching for the name of the cadets in the filing cabinet and in the spreadsheet program. Web-Based and Android Applet has to be applied out since web-based and mobile technology takes place in most of the industry nowadays because of its accessibility. It is expected that the computerization or the application of the information system provides the technical basis to develop sound managerial decisions ${ }^{1,2,3,4,5,6,7,8,9}$.

Using the power of internet technology the researcher proposes to design and develop a cloud-based performance monitoring system which may ease up the flow of the old system and will help reduce the use of papers in encoding and validating the performance of the cadets.
In the present scenario, the retrieval of the report uses the manual-based training record book which causes inconsistency and late submission of reports when it comes to monitoring the performance of the cadets while on board ship training. This is because other shipping companies send their reports after the training period of the cadets. In the proposed monitoring system the summary of report on the performance of the cadets will be directly encoded in the Web Based system by the training officers of the shipping agency. At the same time, the Cadets can also receive the summary of their performance through online notification using the Android Applet. $1,2,3,4$.

\section{Materials and Methods Sampling Technique}

The researcher has use a purposive sampling technique. The researcher will focus on particular characteristic of a population that are to answer the research questions.

\section{The Respondents}

The respondents of the study are the $2^{\text {nd }}$ class cadets and officers of the Department of Shipboard Training (DST) of the Philippine Merchant Marine Academy, San Narciso, Zambales and the officers of the various shipping companies. The respondents were officially enrolled during 2013-2014.

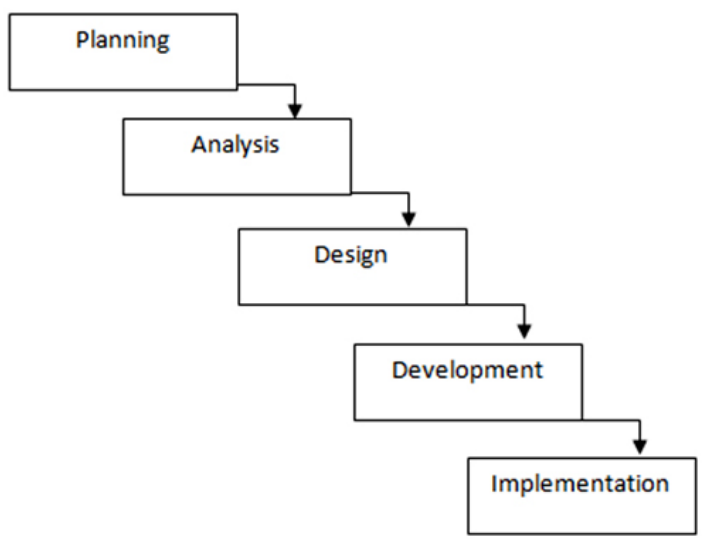

Fig. 1: shows the diagram of the Systems Development and Life Cycle (SDLC) 
Systems Development and Life Cycle is a calculated model utilized as a part of undertaking administration that portrays the stages engaged with a data framework improvement venture, from an underlying possibility ponder through upkeep of the finished application.

\section{Gantt Chart}

\begin{tabular}{|l|l|l|l|l|l|l|l|l|l|}
\hline \multirow{2}{*}{ ACTIVITIES } & \multicolumn{9}{c|}{ PERIOD } \\
\cline { 2 - 9 } & \multicolumn{2}{|c|}{ JANUARY } & \multicolumn{3}{c|}{ FEBRUARY } & \multicolumn{3}{c|}{ MARCH } \\
\hline Planning & & & & & & & & & \\
\hline Analysis & & & & & & & & & \\
\hline Design & & & & & & & & & \\
\hline Development & & & & & & & & & \\
\hline Implementation & & & & & & & & & \\
\hline
\end{tabular}

Fig. 3: Shows the schedules of activities of the development of the Cloud Based Application.

\section{Development}

The researcher had developed a Cloudbased application system using PHP and MySql in order to automate the submission of sea projects done by the cadets and will be monitored by the deck and engine training officers.

A Gantt chart was also used in the development process in order to track down the progress of each phases.

\section{Research Instrument}

Questionnaire has used as a research instrument. The researcher has prepare structured questionnaire for the respondents to be used as a testing phase of the proposed system. The questionnaire consists of two parts. The first part is the respondents' as to age, sex, course and occupation. The second part is the respondents' perception in the existing system and proposed system with regards to the specified parameters such as accuracy, security, maintainability, operability, and speed of processing.

\section{Validation of Research Instrument}

Draft of questionnaire has been made by the researcher. Errors and modifications will be corrected by the thesis adviser to further improve the questionnaire. Final copy of the questionnaire will be distributed to the respondents.

\section{Data Gathering Method}

After answering the questionnaire, it will be immediately retrieved by the researcher from the respondents. The researcher tally the data that were collected from the respondents to were able to compute, analyze and interpret the result that were used in the presentation and analysis of data.

\section{Results and Discussions}

From the findings, the following conclusions which are binding on the respondents are arrived at:

- A typical respondent is between $19-25$ years old above, cadets and officials of the Philippine Merchant Marine Academy.

- The respondents perceived the existing system in terms of the System Quality Metrics as Not Efficient.

- The respondents perceived the proposed Cloud Based Application Performance Monitoring System for the Cadets of the Philippine Merchant Marine Academy in terms of the System Quality Metrics with an overall mean of 4.31 which is significantly higher than the mean of the existing system.

- The computed $t$ is 266.99 with significance level of 0.00 which is lower than the level of significance of 0.05 two tailed, thus the null hypothesis is rejected. This implies that the proposed system shows a significant 
difference in terms of System Quality Metrics

\section{Recommendations}

In view of the findings and conclusions, the researcher would like to recommend the following:

- The proposed Cloud Based Application Monitoring System for the Cadets of the Philippine Merchant Marine Academy, San Narciso, Zambales must be immediately implemented at the Department of Shipboard Training to monitor the performance of the cadets while on boardship training.
The study must be linked to the present website of the Philippine Merchant Marine Academy, San Narciso, Zambales.

- With the implementation of the Cloud Based Application Monitoring System for the Cadets of the Philippine Merchant Marine Academy, San Narciso, Zambales. Continuous maintenance must be employed to make sure its smooth operation over the internet.

Research undertaking must be done to further improve its features and capabilities.

Table 1: Frequency and Percentage Distribution of the Respondents in Terms of Course

\begin{tabular}{lllll}
\hline Courses & \multicolumn{2}{c}{ Existing Group } & \multicolumn{2}{c}{ Proposed Group } \\
\hline & Frequency & Percentage & Frequency & Percentage \\
BSMT & 63 & 48.9 & 65 & 46.8 \\
BSMARE & 62 & 48.1 & 66 & 47.5 \\
Officials & 4 & 3 & 8 & 5.8 \\
Total & 131 & 100 & 139 & 100 \\
\hline
\end{tabular}

Table 2: Test of Difference between the Existing System and Proposed Systems as group in terms of System Quality Metrics

\begin{tabular}{|c|c|c|c|c|c|}
\hline & System & Mean & Computed & Significance & Remarks \\
\hline \multirow[t]{2}{*}{ Accuracy } & Existing & 1.00 & 165.36 & 0.00 & Reject Ho \\
\hline & Proposed & 4.32 & & & \\
\hline \multirow[t]{2}{*}{ Security } & Existing & 1.00 & 187.67 & 0.00 & Reject Ho \\
\hline & Proposed & 4.36 & & & \\
\hline \multirow[t]{2}{*}{ Maintainability } & Existing & 1.00 & 122.72 & 0.00 & Reject Ho \\
\hline & Proposed & 4.34 & & & \\
\hline \multirow[t]{2}{*}{ Operabilty } & Existing & 1.00 & 172.31 & 0.00 & Reject Ho \\
\hline & Proposed & 4.35 & & & \\
\hline \multirow[t]{2}{*}{ Speed Processing } & Existing & 1.00 & 73.52 & 0.00 & Reject Ho \\
\hline & Proposed & 4.20 & & & \\
\hline \multirow[t]{2}{*}{ Average SQM } & Existing & 1.00 & 266.99 & 0.00 & Reject Ho \\
\hline & Proposed & 4.31 & & & \\
\hline
\end{tabular}

Table 1 shows the frequency and percentage distribution of the respondents in terms of course.

As seen from the table, out of 131 respondents from the existing group, 63 or $48.9 \%$ of the respondents are enrolled BSMT, while 62 or $48.1 \%$ are BSMARE cadets and Officials are 4 or $3 \%$. On the other hand, for the proposed group, out of the 139 respondents, 65 or $46.8 \%$ are BSMT, 66 or $47.5 \%$ are enrolled in BSMARE and Officials are 8 or $5.8 \%$, . As implied, the number of respondents as group per course is in parallel to the ratio of the students currently enrolled at PMMA 


\section{Acknowledgment}

The researcher would like to express his sincere heartfelt and deepest gratitude to those who have rendered their time, knowledge, guidance and support to make this work a reality.

Dr. Nemia M. Galang, his very supportive adviser, for her encouragement, precious time and wisdom. Dr. Menchie A. Dela Cruz, his efficient critic, for her patience, dedication and extended assistance to this study.

Dr. Esmen M. Cabal \& Ms. Melojean C. Marave for their encouragement and sincere comments.

Dr. Domingo C. Edaño, the Director of Graduate Studies for giving encouragement to the researcher in pursuing this study.

MR. RAMON G. LACBAIN II, Former Zambales ViceGovernor for approving and giving him a financial assistance in pursuing his study.

VADM RICHARD U RITUAL PMMA, Superintendent of the Philippine Merchant Marine Academy, for his consideration, understanding and support.

Engr, Patrick Entendez, Director of Shipboard Training for his accommodation and support in the administration of his questionnaire and providing the data needed by the researcher, but moreover, for encouraging him to pursue his graduate studies.

His Friends, Marijoy S. Pagal, Engr, Melchor M. Millar C/E Charlie M. Pandongan, Engr. Arnold Pasamba, PSITE Region III Officers, Dr. Dave Marcial, Dr. Grace Tyler of Systems Plus College Foundation, Engr. Alessandro Ong, Ms. Jessa Delos Santos Ladringan, Rev. Father Willie Monsalud, Rev. Father Dexter Magno, Rev. Father Ferdinand Fajardo, Knights of Columbus Council 10103 and my AMA Olongapo Family.

To his cousins Vivian Delute and Rebecca Lugatiman in giving their support and guidance in this study.

To his loving and supportive family, for their prayers, support and encouraging words.

To all his friends in Philippine Merchant Marine Academy and PMMA's 1st Class Midshipmen Batch 2014, who had assisted in distributing the questionnaires.

And above all, to God Almighty, for showering the writer all the love, guidance and blessings.

\section{References}

1 Assessment of Online Grading System, (2011) Retrieved from http://www.studymode. com/essays/Assessment-Of-Online-GradingSystem-765775.html

2 E Profiling Foreign and Local Literature., (2013) Retrieved from Profiling Foreign-AndLocal- Literature-1931219.html

3 dela Pena-Bandalaria, Melinda (2014) Impact of ICTs on Open and Distance Learning in a Developing Country Setting: The Philippine experience

5

7 from the http://www.antiessays.com/freeessays/109531.html
6

s

Marrero, Philippines (2009) Student Information System for the University of the Cordilleras, Cordillera

Ramos, Andrienne Gail E, (2011) Online Grading System of Canossa School Palacio, Rochelle (2014) Student Information Systems, http://www.studymode.com/essays/ Student-Information-System-Of-BenguetPhil-1880085.html

8 Silberchatz, Korth and Sudashan, (2010) Database System Concepts, New York City, USA

9 Stair, Ralph, (2008) Fundamentals of Information Systems, USA 